\title{
THE INFLUENCE OF MANGAROCK ONLINE COMICS IN TEACHING WRITING A NARRATIVE TEXT
}

\author{
${ }^{1}$ Muhamad Sofian Hadi, ${ }^{1}$ Lidiyatul Izzah, \& ${ }^{2}$ Ineke Larasati \\ ${ }^{1}$ English Lecturer, FKIP, Muhammadiyah University of Jakarta, Indonesia \\ ${ }^{3}$ English Student, FKIP, Muhammadiyah University of Jakarta, Indonesia \\ Corresponding Author Email: inekelara@gmail.com
}

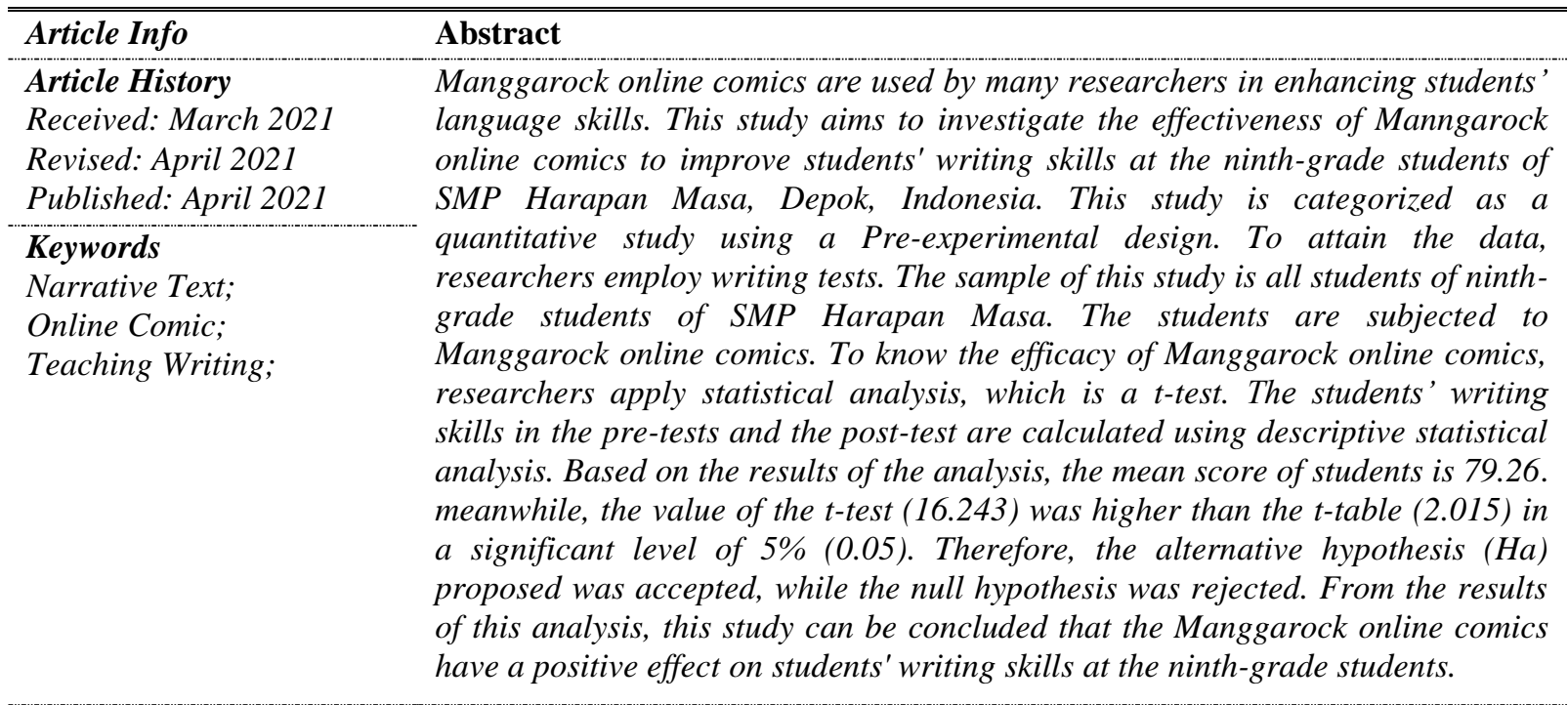

How to cite: Hadi, M. S., Izzah, L., \& Larasati, I. (2021). The influence of mangarock online comic in teaching writing a narrative text, JOLLT Journal of Languages and Language Teaching, 9(2), 243-249, DOI: https://doi.org/10.33394/jollt.v\%vi\%i.3546

\section{INTRODUCTION}

Many studies inform that understanding a language needs a long process because language is a complex and dynamic system. Because a language is complex, the accuracy, fluency, and complexity progress cannot be totally seen by performance in any subsystem (Hundt, 2019; Alfulaila et al., 2019; Wee, 2018; Sitorus \& Sipayung, 2018). Writing skill is a subset of students' language competence, with an emphasis on writing abilities. Students are demanded to produce various genres and rhetorical features and include language-specific abilities such as vocabulary and syntactic structures (Lahuerta, 2018; Baroudy, 2008). In EFL contexts, writing is considered the most difficult language skill to be mastered. Due to this, English teachers employ various learning methods, strategies, and techniques to help students develop their writing performance.

In addition, writing requires students to be able to organize their cognition, sociocultural, and linguistics aspects since they write ideas into papers (Haerazi \& Irawan, 2020; Song, 2019; Raigon-rodriguez, 2018). Composing texts, such as planning, drafting, revising, and editing, is employed by EFL teachers in their writing classes. At any stage of writing, students are demanded to use strategies or approaches to help them carry out their acts of writing (Mishima, 2019). Therefore, EFL teachers should arrange their writing classes in order they facilitate students to improve their writing skills. In this study, the Mangarock online comics are presented to help students in enhancing their writing skills. Many EFL 
teachers have already applied this medium, but the use of digital comics for the teaching of writing skills has not been extensively conducted yet.

Digital comics are categorized as electronic comics that are posted digitally (Ferdiansyah, 2018; Jang \& Song, 2017; Susilawati, 2017; Winarti et al., 2018). Digital comics also are divided into two forms; online and offline. When the teachers download or print the online comics, it becomes offline comics. The contents of digital comics are presented in the form of school life, romance, comedy, historical, tragedy, horrors, fiction, gender, etc. these contents can be designed to facilitate students to improve their language skills. This study tries to improve students' writing skills using digital comics, which are Mangarocks comics. Writing is a complex skill. According to Muschla (2011), good writing starts with a good idea. Writing is a language skill that plays an important role in daily life. To help students practice to write, this study provided students with narrative texts. In general, narrative texts tell about actions or events. Narrative texts have a social function to entertain, entertain, and address real experiences or experiences in different ways (Rambe, 2017).

Digital comics can attract and encourage high-achieving language learners to write in English. The interesting features of this digital comic seem undeniable (Yunus et al., 2012). Engagement with the digital arts in which software programs allow for experimentation and expression through color, line, font, image, and narrative creates opportunities for students to express their responses to literature in exploratory ways across multiple sign systems (Yeung, 2016). As researchers, analytical lenses attuned to the arts and aesthetics also enhanced our analyses of students' comics (Wissman \& Costello 2014: 116). This media is also available as a downloadable online application. There are many comic stories available on the online comic media application Mangarock. The researchers take a comic story from this media according to the students' grades. After that, researchers ask students to rewrite the narrative text story to develop students' ideas in understanding text narrative writing. It is in line with Javed et al. (2013) carried out in the study.

This study aims to find out the effectiveness of Mangarock online comics in enhancing students' writing skills at SMP Harapan Masa. In the current study, the Mangarocks online comics are a teaching medium employed in writing classes. The learning processes are carried out in online learning. To help researchers, the teaching-learning approaches used product approach, process approach, and genre approach. Therefore, the novelty of this study lies on the use of various approaches to facilitate students to improve their writing skills using Mangarocs online comics.

\section{RESEARCH METHOD Research Design}

In this study, researchers used a quantitative study with a pre-experimental research design. This study is aimed at finding out the effect of the Mangarock online comics on students' writing skills at the ninth-grade students. According to Creswell (2014), quantitative research focuses on numerical, fixed, and detailed data. This research is used in one class. There is no control class in this study because this study applies a pre-experimental design. A variable is a feature in a study or a measurable number of events. The students are subjected to Mangarock online comics. The meeting was carried out in 4-5 meetings. Before treatments, students are tested using pre-test writing. It aims to see the students' writing ability. During the treatment process, researchers collaborate with the existing writing teachers. Mostly, the existing teachers acted as teachers in giving the students treatments.

\section{Population and Sample}

This research was conducted online. The population in this study all of class 9 grade of SMP Harapan Massa were consist 200 students with into 5 classes. In this research, the researcher was randomly choose one class only as the sample of this research., that is VIII-1 
grade in SMP Harapan Massa it consists of 23 students. There is 17 female and 6 male in this class. The samples are treated using Mangarock online comics to improve their writing skills. In the current study, the samples are provided with various writing exercises of narrative texts. They are also involved in making graphic-organizer forms of narrative texts.

\section{Instruments}

The instrument of this study uses writing tests. The tests are used to attain the students' writing achievement. The writing tests are in the form of writing a complete narrative text. The writing test is carried out in two sessions, the pre-test, and post-test sessions. Students are given the writing test in the pre-test to see the students' writing skills before giving them a specific treatment, which is Mangarock online comics. In the tests, students are asked to produce a complete narrative text. The writing assessment focuses on students' writing contents, organization, vocabulary, grammar, and mechanics.

\section{Data Analysis}

The data of this study are students' writing achievements in the pre-test and post-test. The data are analyzed using statistical analysis, which is descriptive and inferential analysis. The descriptive analysis is focused on students' mean, mode, and median scores. The score is collected using writing tests at the end of treatments. Meanwhile, the inferential analysis is carried out using a t-test. The t-test analysis aims to see the significant difference of students' writing achievement in the pre-test and post-test. To take conclusion, researchers decide that if the value of the t-test is greater than the value of the t-table, the Mangalocks online comics are effective in improving students' writing skills. But, if the value of the t-test is lower than the t-table, the online comics are not effective in improving students' writing skills. Based on the result of the analysis, the value of the t-test was higher than the t-table. The process of the data calculation is assisted by using SPSS devices.

\section{RESEARCH FINDINGS AND DISCUSSION Research Findings}

In this section, the researcher explains the collected data during the study conducted at SMP Harapan Massa. In the sample of this study, one class was an experimental class. In the first meeting, all class was given a pre-test to measure their narrative texts. After the process of collecting the pre-test data, the researcher prepared the teaching materials and implemented mangarock online comic to improve students writing skills. The treatment was conducted for six meetings. At the last meeting, the researcher gave the post-test. The result of the test was used as a reference for the author to analyze the students 'improvement in writing skills.

Table 1

The Experimental Class Students' Pre-test writing skill

\begin{tabular}{lcc}
\hline $\begin{array}{c}\text { Students' writing } \\
\text { skill level }\end{array}$ & $\begin{array}{c}\text { Total number of } \\
\text { students }\end{array}$ & $\begin{array}{c}\text { Total number of the } \\
\text { students in percentage }\end{array}$ \\
\hline Very poor & 7 & $30,43 \%$ \\
\hline Poor & 16 & $59,3 \%$ \\
\hline Enough & 0 & $0 \%$ \\
\hline Good & 0 & $0 \%$ \\
\hline Excellent & 0 & $0 \%$ \\
\hline
\end{tabular}

The Mangarocks online comics are designed to improve students' writing skills. EFL teachers involve students in various writing exercises using digital comics. The type of digital comics includes story comics and fictions comics. Both are considered representative teaching materials for teaching writing skills. Due to this, students feel easy to compose simple sentences and paragraphs. Before teaching students using digital comics, students have low 
writing performance. Table 1 shows that most students have low writing skills in the pre-test session. Students perform writing skills at a very poor level $(30,43 \%)$, and $59.3 \%$ of students are a poor level. The students' writing performance is seen in different results from the pretest. In the post-test, the use of Mangarocks online comics is able to improve students' writing skills. The results can be presented in Table 2 as follows.

Table 2

The Experimental Class Students' Post-test writing skill

\begin{tabular}{lcc}
\hline $\begin{array}{c}\text { Students' writing } \\
\text { skill level }\end{array}$ & $\begin{array}{c}\text { Total number of } \\
\text { students }\end{array}$ & $\begin{array}{c}\text { Total number of the } \\
\text { students in } \\
\text { percentage }\end{array}$ \\
\hline Very poor & 0 & $0 \%$ \\
\hline Poor & 3 & $13,04 \%$ \\
\hline Enough & 7 & $30,43 \%$ \\
\hline Good & 13 & $56,52 \%$ \\
\hline Excellent & 0 & 0 \\
\hline
\end{tabular}

The popularity of Mangarock digital comics affects students to accomplish their writing exercises effectively. Digital comics provide students with images and texts. It attracts students' attention. Through this medium, teachers distribute their materials to students. Because of this, students can practice writing easily. They can create various simple narrative texts. Table 2 shows that students perform their writing at a poor level $(13,04 \%)$, in enough level $(66,6 \%)$, and at a good level $(30,43 \%)$. Based on the category level, there is no student in the very poor level and excellent level.

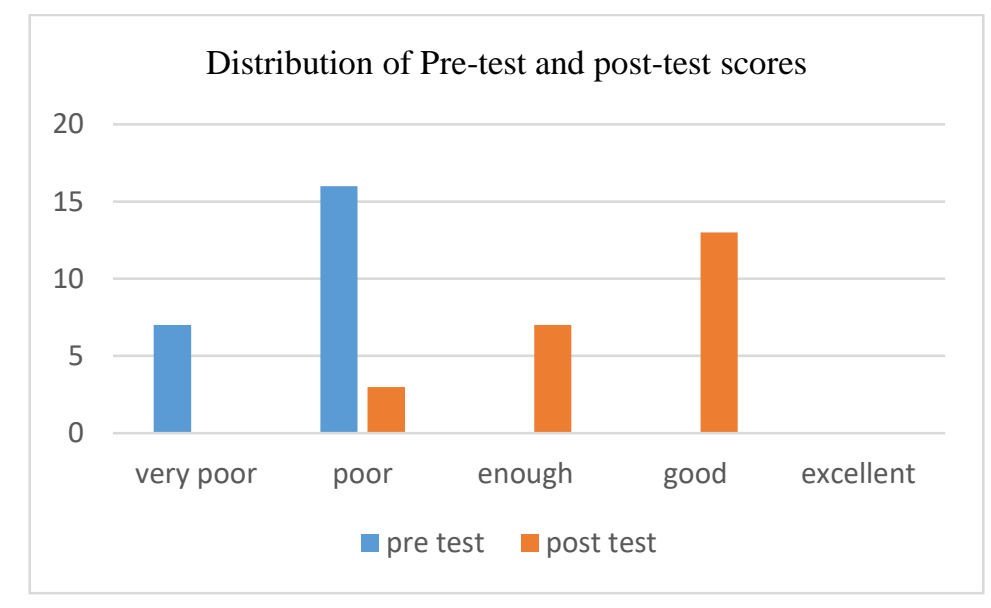

Figure 1. Diagram of Frequency Distribution of Pre-Test and Post-Test

Based on the students 'pre-test and post-test results in Figure 1, researchers analyzed the results to determine the effect of the Mangarocks online comics on students' ability to write narrative texts. The writer calculated based on the t-test formula steps as follows. Based on the calculation above, the result is $16.243>2.015$. The result of the data analysis showed that by using the $t$-test formula, the result of $t_{\text {cal }}$ is 16.243 higher than $t_{\text {table }} 2.015$. This means that Mangarock online comic can influence students' writing skills. It means most students are categorized as enough writing competence. In other words, the use of mangarocks online comics has a positive effect on students' writing skills at SMP Harapan Masa. 


\section{Discussion}

This study is aimed at investigating the effectiveness of Mangarocks online comics on students' writing skills at SMP Harapan Masa. The students are provided with learning media, Mangarock online comics. In the teaching-learning activities, researchers applied various learning approaches, such as product-based learning approach, process-based learning approach, and genre-based learning approach. The approaches are employed to support students in generating narrative texts. It is in line with Muyassaron et al. (2019) who argue that the use of digital comics is effective when teachers apply the approaches in writing classes. The incorporation of Digital comics offers opportunities for students to use their writing strategies. Students start from the drafting process to the editing stages.

The use of Mangarocks digital comics helps students to improve their motivation to accomplish their writing tasks. It is also confirmed by Zemach (2010), who studied that the use of digital comics can increase students' motivation and make learning easier to manage. In the current study, the use of Mangarock online comics encourages students to compose their sentences and paragraphs. For instance, they are able to create various introductory paragraphs of narrative texts. Besides, the online comics promote students' motivation in group writing collaboration and collaborative writing activities. These findings are found by other researchers, such as Muyassaroh et al. (2019) and Zemanch (2010).

In this study, students are asked to read some texts which are suitable with stories in comics. They are also involved in discussion groups. This aims to build students' background knowledge of the topic before going to write. In doing so, students are provided with comic strips which capture all essence in a narrative way. Students are then drafting any information relating to the writing topics. The drafting activities are directed to compose a complete introductory paragraph of narrative texts. It is very effective to lead students in writing collaboration. Students ask other students when they have unfamiliar vocabulary. This learning atmosphere is found as well by Alves et al. (2007) and Lucas et al. (2010) who inform that digital comics in the form of stories enable students to enhance their language use and advance their vocabulary.

The efficacy of using Mangarocks online comics was effective in improving students' writing skills. It is proven by the result of students' achievement in which the value of the ttest (16.24) was higher than the t-table (2.015) in the degree of the significance level of 5\%. It means the alternative hypothesis $\left(\mathrm{H}_{1}\right)$ was accepted while the null hypothesis $\left(\mathrm{H}_{0}\right)$ was rejected. Thus, it can be concluded that the Mangarock online comics have a positive effect on students' writing skills at the ninth-grade students of SMP Harapan Massa in the academic year of 2020-2021. The other researchers can use the theoretical basis of this study to carry out other studies dealing with digital comics.

\section{CONCLUSION}

After presenting and analyzing data in the previous chapter, the writer concluded that online comics could improve students' writing skills. It can be seen from the students' improvement between pre-test and post-test. Based on research in class IX SMP HARAPAN MASSA, it can be concluded that the Mangarock online comics can influence students in writing skills. This can be seen from the student's process of improving students' narrative writing. Student progress can be seen from the results of student predictions and post-test, student prediction results (79.26), and student pre-test results (54.17). This means that the students' sense of accomplishment has increased, and their post-test scores are higher than their pre-test scores. It also shows that when the significance is $5 \%$, the t value is higher than the $t$ table. If the t-test result is higher than the stable level, then the alternative hypothesis is accepted, and the null hypothesis is rejected. Based on the results of the t-test calculation above, because of the acceptance of the alternative hypothesis, it can be said that learning activities using Mangarock online comics can influence students' writing skills. 


\section{ACKNOWLEDGEMENTS}

First of all, researchers would like to pray to Allah SWT, who has blessed them with beautiful things in their life and who has empowered them to finish this study. Also, researchers would like to express my warm gratitude to those who have contributed to finishing this study with their comments and suggestions to make this study more easily understood. Researchers also thank JOLLT (Journal of Languages and Language Teaching) team-editors who help this article with revisions and suggestions.

\section{REFERENCES}

Alves, T.,McMichael, A., Simoes, A., Vala, M., Paiva, A \&Aylett, R. (2007). Comics 2D: Describing and creating comics from story-based applications with autonomous characters, http://www.researchgate.net/publication/228359599_Comics2D_Describing_and_creati ng_comics_from_story-based_applications_with_autonomous_characters, accessed 15 July, 2020.

Alfulaila, N., Haryadi, Sudrajat, A., \& Nashrullah. (2019). The effectiveness of multicultural approach in writing achievement of Indonesian language among elementary school students. Cakrawala Pendidikan, 38(2), 366-376. https://doi.org/10.21831/cp.v38i2.23440

Baroudy, I. (2008). Process Writing: Successful and Unsuccessful Writers; International Journal of Language Studies, 8(2), 43-63.

Deligianni-Georgaka, A., \& Pouroutidi, O. (2016). Creating digital comics to motivate young learners to write: a case study. Research Papers in Language Teaching and Learning, 7(1), 233.

Ferdiansyah, S. (2018). Collaborative narrative writing: A digital photography task in an Indonesian Islamic secondary school. Indonesian Journal of Applied Linguistics, 8(2), 303-315. https://doi.org/10.17509/ijal.v8i2.13277

Haerazi, H., \& Irawan, L. A. (2020). Developing Intercultural Language Learning (ILL) model to teach writing skills at Indonesian private universities. EduLite: Journal of English Education, Literature and Culture, 5(1), 43. https://doi.org/10.30659/e.5.1.43-54

Hundt, M. (2019). 'My language, my identity': negotiating language use and attitudes in the New Zealand Fiji Indian diaspora. Asian Englishes, 21(1), 2-21. https://doi.org/10.1080/13488678.2018.1463148

Jang, W., \& Song, J. E. (2017). Webtoon as a New Korean Wave in the Process of Glocalization. Kritika Kultura, 2017(29), $168-187$. https://doi.org/10.13185/KK2017.02908

Javed, M., Juan, W. X., \& Nazli, S. (2013). A Study of Students' Assessment in Writing Skills of the English Language. International Journal of Instruction, 6(2), 129-144.

Lahuerta, A. C. (2018). Study of accuracy and grammatical complexity in EFL writing. International Journal of English Studies, 18(1), 71-89. https://doi.org/10.6018/ijes/2018/1/258971

Lucas, R.,I., Pulido, D., Ignacio, A., Tacay, M. \& Lao, J. (2010). 'A study on the intrinsic motivation factors in Second Language Learning among selected freshman students.' Philippine ESL Journal, 4:3-20.

Mishima, M. (2019). Re-Conceptualizing L2 Writing Revision Strategies From an Ecological Perspective: an Interview Based Inquiry. English Review: Journal of English Education, 7(2), 1. https://doi.org/10.25134/erjee.v7i2.1771 
Muschla, G. R. (2018). Practice Makes Perfect Exploring Writing. McGraw Hill Professional.

Muyassaroh, M. N., Asib, A., \& Marmanto, S. (2019). The Teacher's Beliefs and Practices on the Use of Digital Comics in Teaching Writing: A qualitative case study. International Journal of Language Teaching and Education,3(1), 45-60. https://doi.org/10.22437/ijolte.v3i1.6502

Raigón-Rodríguez, A. (2018). Analysing cultural aspects in EFL textbooks: A skill-based analysis. Journal of English Studies, 16, 281-300. https://doi.org/10.18172/jes.3478

Rambe, S. (2017). Communicative Languange Teaching. English Education, 5(2), 54-66.

Sitorus, G. S., \& Sipayung, K. (2018). An Error Analysis of Using Phrases in Writing Recount Text at Tenth Grade in SMA Parulian 2 Medan. Celt: A Journal of Culture, $\begin{array}{lllll}\text { English Language Teaching \& Literature, } & 18(1), & \end{array}$ https://doi.org/10.24167/celt.v18i1.562

Song, B. (2019). Exploring the cultural content in Chinese ELT textbooks from intercultural perspectives. Journal of Asia TEFL, 16(1), 267-278. https://doi.org/10.18823/asiatefl.2019.16.1.17.267

Susilawati, F. (2017). Teaching Writing of Narrative Text through Digital Comics. Journal of English and Education, 5(2), 103-111

Wee, L. (2018). World Englishes, Second Language Acquisition, and the linguistic system conundrum. World Englishes, 37(1), 51-63. https://doi.org/10.1111/weng.12302

Winarti, H., Masrupi, \& Juniardi, Y. (2018). English Digital Comics for the Students of Senior High School in Banten. In AISELT (pp. 231-240).

Wissman, Kelly, K., \& Costello, S. (2014). Creating Digital Comics in Response to Literature: Aesthetics, Aesthetic Transactions, and Meaning Making. Journal of Language Arts, 92(2) pp. 103-116.

Yeung, M. (2016). Exploring the Construct of Learner Autonomy in Writing: The Roles of Motivation and the Teacher. English Language Teaching, 9(8), pp. 122-139.

Yunus, M. M., \& Salehi, H., \& Embi, M. A. (2012). Effects of Using Digital Comics to Improve ESL Writing. Research Journal of Applied Sciences, Engineering and Technology, 4(18), pp. 3462-3469. 